\title{
Drifting in the oceans: Isarachnanthus nocturnus (Cnidaria, Ceriantharia, Arachnactidae), an anthozoan with an extended planktonic stage
}

\author{
Sérgio N. Stampar ${ }^{1} \cdot$ André C. Morandini $^{2} \cdot$ Laura C. Branco $^{3}$. \\ Fábio Lang da Silveira ${ }^{2} \cdot$ Alvaro E. Migotto $^{3}$
}

Received: 22 July 2015 / Accepted: 29 September 2015 / Published online: 12 October 2015

(C) Springer-Verlag Berlin Heidelberg 2015

\begin{abstract}
The life cycles of many marine taxa are still unknown, especially those species with indirect development and long-lived larval stages. Life cycles of cnidarians are relatively well known for most groups except Ceriantharia. This taxon presents taxonomic problems stemming from the lack of association between planktonic larval forms, often described as distinct species, with the corresponding adult benthic stages. Our study focused on the development of larvae with peculiar external morphology that could be linked to a described species established from adult specimens. Through cultivation of these larvae to juveniles with adult-like morphology and also with the use of DNA barcoding, it was possible to link the stages observed to a known species, Isarachnanthus nocturnus. Based on life span of the larva in the plankton (63-118 days), the larvae could potentially drift for about 2000-4000 km along the coast. Because rearing larvae in the laboratory may be complex and time-consuming and also because morphological data may have limited
\end{abstract}

Responsible Editor: J. Purcell.

Reviewed by B. Picton, J. D. Reimer.

Sérgio N. Stampar

stampar@assis.unesp.br

1 Departamento de Ciências Biológicas, Faculdade de Ciências e Letras de Assis, Unesp - Universidade Estadual Paulista, Assis, Av. Dom Antonio, 2100, Assis 19806-900, Brazil

2 Departamento de Zoologia, Instituto de Biociências, Universidade de São Paulo, Rua do Matão, trav. 14, no. 101, São Paulo 05508-090, Brazil

3 Centro de Biologia Marinha, Universidade de São Paulo, Rodovia Manoel Hipólito do Rego, km. 131,5 - Praia do Cabelo Gordo, São Sebastião, SP 11600-000, Brazil distinguishing power for specific identification of larvae collected in the field, we suggest and discuss the use of DNA barcoding as a tool to connect life stages of species of cerianthids and invertebrates in general.

\section{Introduction}

For most sessile benthic species, the primary dispersal phase is normally represented by the earliest life-history stages, such as free-swimming embryos and planktonic larvae (Cowen and Sponaugle 2009). Precise identification of these propagules at species level is essential for estimating dispersal and for understanding population connectivity and distribution patterns. Identification to species level based on morphology alone is often inaccurate or even impossible, as larvae of closely related species usually share common morphological features. Also, in general, taxonomy is based on adults, as the early life-history stages have a simple morphology, often very distinct from the adult. When lifehistory stages are unknown, linking larva to adult and vice versa depends on direct studies of the life cycle or the availability of molecular data as a means of linking larval stages to known adults (e.g., Ko et al. 2013; Bernal et al. 2014).

Studies on the behavior and life cycle of cnidarian species in the laboratory and in situ are still rare for many groups of cnidarians, especially Ceriantharia (Tiffon 1987), although such studies are essential to identifying the species and populations (e.g., Jarms et al. 2002).

Members of the subclass Ceriantharia, commonly known as tube anemones, are relatively large sessile animals that live semi-buried in the sediment (Stampar et al. 2014a). They produce pelagic larvae that resemble medusae, with a circlet of marginal and labial tentacles. Many genera and species have been named solely from the 
pelagic larvae, while the adults and their life cycle remain unknown (Molodtsova 2004). Some authors (e.g., Leloup 1964) have treated these planktonic ceriantharians as valid species, while others believe that they must be larval or young stages of benthic species (see Tiffon 1987; Molodtsova 2004). Knowledge of the life cycles and the connection between planktonic and benthic stages makes it possible to gradually eliminate the double taxonomy that is still in use, which has caused systematic problems and may hinder the evaluation of the family's biodiversity-a problem analogous to the double taxonomy of polyps and medusae of Hydrozoa (Nyholm 1943; Naumov 1969; Jarms 1990). Only a few studies on Ceriantharia have elucidated the connection between planktonic and benthic forms (e.g., Nyholm 1943). As a case in point, a long-existing misidentification of a pelagic species (Tessera gemmaria), which was considered to be a stauromedusan, was recently recognized as a planktonic larval stage of a member of Ceriantharia (Rodriguez et al. 2011).

Until now, life cycles of ceriantharian species can be divided into two general types: long-term larvae lasting several weeks in the water column (different morphology in each case) and short-term larvae (planula-like) lasting only a few hours in the plankton (Nyholm 1943; Uchida 1979; Tiffon 1987). However, this classification was developed based only on individuals of the family Cerianthidae. The life cycles of the other two families, Arachnactidae and Botrucnidiferidae, are completely unknown. Some specimens of Arachnactidae (Arachnactis albida) have been observed in plankton time series, but without exact correlation with benthic species (Sars 1846; van Beneden 1898).

Traditionally, linking larvae to adults, and vice versa, depends on direct studies of the life cycles; however, rearing larvae in the laboratory may be complex and timeconsuming, particularly for species with long-lived larval stages (Jarms et al. 2002). Also, morphological data may have limited distinguishing power for specific identification of larvae collected in the field, due to phenotypic plasticity in larval morphology as well as variation in life-cycle patterns, for species with complex life cycles (e.g., Boero et al. 1992; Minelli and Fusco 2010). By contrast, DNA barcoding is very efficient for this and can be applied to virtually all taxonomic groups and in preserved specimens (Weeb et al. 2006; Heimeier et al. 2010).

This contribution describes the larval development, settlement and polyp growth of Isarachnanthus nocturnus, a species of the family Arachnactidae from the western South Atlantic Ocean. It is also shown, for the first time, that DNA barcoding is an effective and relatively cheap method for the identification of larval cerianthids, and if widely employed could substantially enhance the knowledge of biodiversity of the subclass Ceriantharia.

\section{Materials and methods}

\section{Sampling and rearing}

Three larvae were collected in three different years (May 5, 2012, Larva A; May 15, 2013, Larva B; and May 30, 2014, Larva C), in the São Sebastião Channel (southeastern Brazil, $\left.23^{\circ} 49^{\prime} 52^{\prime \prime} \mathrm{S} 045^{\circ} 24^{\prime} 39^{\prime \prime} \mathrm{W}\right)$ with a standard plankton net (300 $\mu \mathrm{m}$ mesh size) towed horizontally at the sea surface. The larvae were kept in an aquarium (closed system) with aeration at the water surface causing a slight circulation. This system was maintained in dim light (with a black box placed over the aquarium) and a thin layer $(\sim 1 \mathrm{~cm})$ of sand on the bottom. The water circulation helped the larvae to remain above the bottom. Newly hatched nauplii of Artemia sp. and concentrated freshly collected plankton were offered daily. The larvae were kept in this system until they settled (burrowed in the sand). Each newly settled larva was moved to a glass bowl (15 cm diameter, 0.51 volume) with sand, and the bowl was placed in a larger aquarium (100 1). The young polyps were kept in this system until the end of the observations, and were observed and documented daily. Larva and adult specimens were deposited in Museu de Zoologia da Universidade de São Paulo, MZUSP 1478 and others (detailed data in GenBank record).

\section{Species identification}

As few larvae were available and our goal was to follow and describe the life cycle, we did not preserve the larvae. The identification was based on rearing the larvae and on molecular data, as defined by Stampar et al. (2012, 2014b) and Stampar and Morandini (2014). DNA was extracted using InstaGene (Bio-Rad) from single tentacles removed from the polyps just after settlement. Genes were amplified using the PCR technique, and then the PCR products were purified with the AMPure ${ }^{\circledR}$ kit $\left(\right.$ Agencourt $^{\circledR}$ ). The PCR primers CB1 and CB2 (Cunningham and Buss 1993) were used to amplify part of the $16 \mathrm{~S}$ gene (expected fragment of 435-681 bp), and LCO1490 and HCO2198 (Folmer et al. 1994) to amplify part of the COI gene (expected fragment of 670-804 bp) (mitochondrial markers, ribosomal and protein-coding genes, respectively). Primers jfITS-5f (Dawson and Jacobs 2001) and CAS28sB1d (Ji et al. 2003) were used to amplify the target fragment of the nuclear ribosomal unit, including the complete internal transcriber spacer 1 (expected fragment of 121-129 bp), the $5.8 \mathrm{~S}$ ribosomal subunit and the internal transcriber spacer 2 (expected fragment of 203-227 bp). Sequences were assembled and edited using Geneious ${ }^{\mathrm{TM}} 6.1$ (Drummond et al. 2002). The alignment in each molecular 
Table 1 Observations on earlystage larvae of Isarachnanthus nocturnus collected in the São Sebastião Channel, southeastern Brazil

\begin{tabular}{llcl}
\hline Collection date & $\begin{array}{l}\text { Larva A } \\
\text { May 5, 2012 }\end{array}$ & $\begin{array}{l}\text { Larva B } \\
\text { May 15, 2013 }\end{array}$ & $\begin{array}{l}\text { Larva C } \\
\text { May 30, 2014 }\end{array}$ \\
\hline Height of column when collected (mm) & 1 & 1 & 0.4 \\
No. of marginal tentacles when collected & 8 & 7 & 4 \\
No. of labial tentacles when collected & 0 & 0 & 0 \\
Time until settlement (days) & 63 & 119 & 68 \\
\hline
\end{tabular}

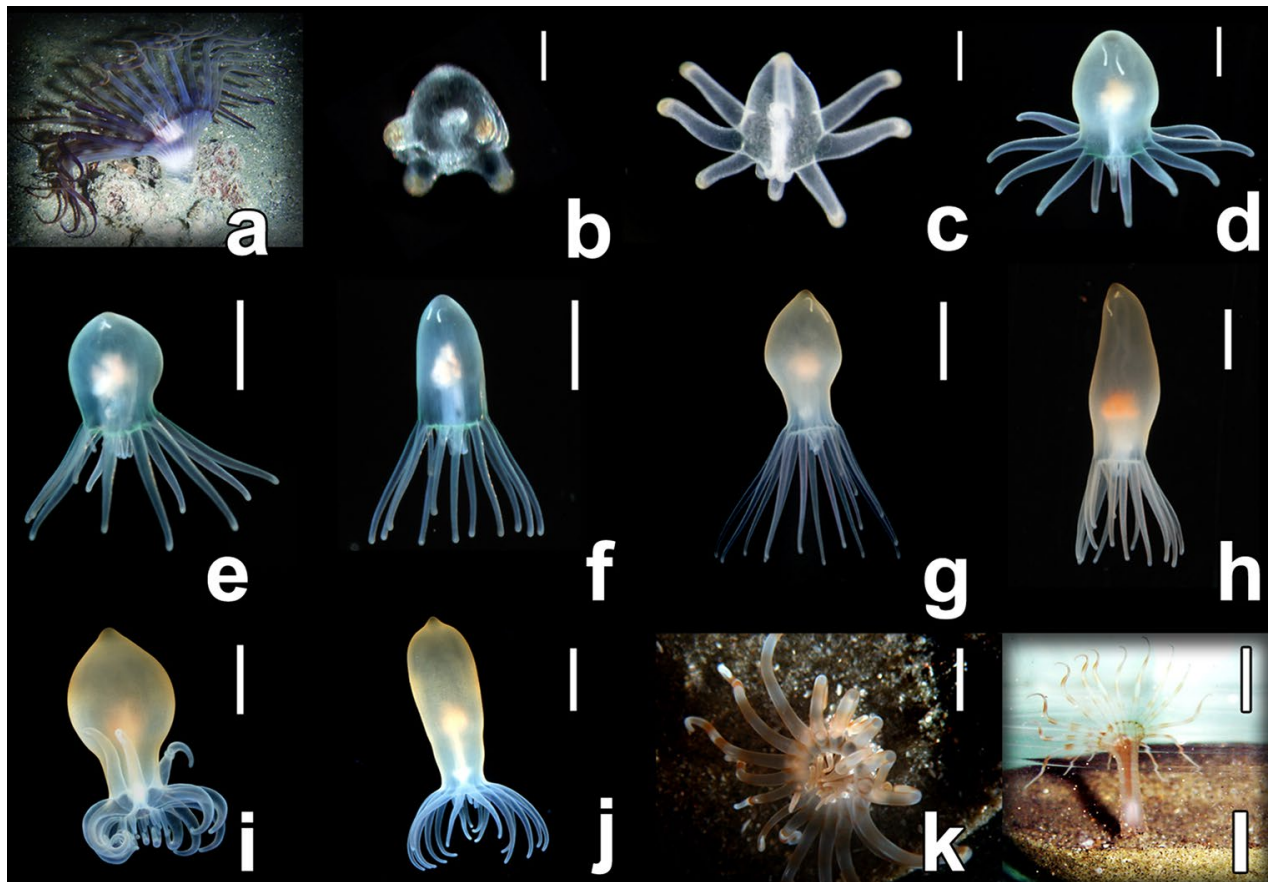

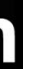

Fig. 1 Images of different stages of the life cycle of Isarachnanthus nocturnus, from São Sebastião Channel, southeastern Brazil. a Adult; b recently collected larva, probably a few hours old; c 2-day-old larva with 7 tentacles; d 18-day-old larva with visible acontioids in $M$-mesenteries; $\mathbf{e}$, g larva between 20 and 30 days old with transparent stretching column and labial tentacles; $\mathbf{h}$ 40-day-old larva; i 50-day-old larva showing more-intense coloration; j 60-day-old larva with aboral pore; $\mathbf{k} 70$-day-old individual already metamorphosed; l 100-day-old individual extending out of the sand. a no scale; b $0.3 \mathrm{~mm}$; c $0.5 \mathrm{~mm}$; d $1 \mathrm{~mm}$; e $4 \mathrm{~mm}$; f $5 \mathrm{~mm}$; g, h $6.5 \mathrm{~mm}$; i $8 \mathrm{~mm}$; j $8 \mathrm{~mm}$; $\mathbf{k} 10 \mathrm{~mm}$ and $115 \mathrm{~mm}$ marker was done using MUSCLE in default parameters (Edgar 2004). New sequences were submitted to GenBank [numbers JF915197 (COI), JF915192 (16S) and JX125641 (ITS)]. Kimura's two-parameter model of base substitution was used to calculate genetic distances in MEGA5 software (Tamura et al. 2011).

\section{Results}

\section{Species identification}

The DNA extracted from tentacles of the three specimens was analyzed using four molecular markers (16S, COI, ITS1 and ITS2) and compared with data available from Stampar et al. (2012). The divergence of these gene markers was nonexistent compared with the population of benthic I. nocturnus from Segredo Beach at CEBIMar-USP on the São Sebastião Channel. The sequences obtained for the three specimens were exactly the same.

\section{Life cycle}

General life-cycle observations such as size and morphology when collected, and time until settlement are presented in Table 1. Just after settlement, the larvae started to burrow and remained in the sediment for 4-7 days; after this time the polyps emerged, already with the adult morphology.

\section{Description of stages (Fig. 1a-j; Tables 1, 2)}

\section{Larva (4-16 marginal tentacles)}

The larvae were approximately cone- or ball-shaped, slightly higher than broad, with a circle of 4 (Larva C), 7 (Larva B) or 9 (Larva A) marginal tentacles. The large slitlike mouth was at the top of a prominent conical projection situated in the center of the oral disk. The tentacles were transparent, short and thick, with dark, rounded and slightly swollen tips. The tentacles were positioned perpendicularly to the oral/aboral longitudinal axis of the body, remaining quite rigid and motionless most of the time. The larvae had 
Table 2 Development time (days) from early larval stage to newly settled polyp of Isarachnanthus nocturnus

\begin{tabular}{|c|c|c|c|c|c|c|c|}
\hline Specimen & 8 marginal tentacles & First labial tentacle & 4 labial tentacles & $\begin{array}{l}12 \text { marginal ten- } \\
\text { tacles }\end{array}$ & $\begin{array}{l}15 \text { marginal ten- } \\
\text { tacles }\end{array}$ & $\begin{array}{l}16 \text { marginal ten- } \\
\text { tacles }\end{array}$ & Settlement \\
\hline Larva A & 0 & 5 & 8 & 20 & 45 & 62 & 63 \\
\hline Larva B & 4 & 6 & 10 & 29 & 53 & 84 & 119 \\
\hline Larva C & 9 & 11 & 14 & 30 & 42 & 64 & 68 \\
\hline
\end{tabular}

nearly neutral buoyancy; in still water, they floated near the surface, with the mouth facing downward, slowly rotating on the longitudinal axis due to the beating of the cilia covering the entire body surface. When placed in a Petri dish, they glided slowly with the aboral end directed forward. The pharynx, the directive mesenteries and the first pair of protomesenteries (Fig. 1c), and the parenchymal cells that filled most of the gastrovascular cavity were partially visible through the translucent body. The column became more rounded after 5-10 days. After a few more days, the area occupied by the parenchymal cells gradually decreased, opening space in the gastrovascular cavity while new mesenteries were added. Observation of these mesenteries was possible only during the first 20-25 days, after which the larvae acquired a milky-white color, losing transparency. After 20 days, Larva A was $8 \mathrm{~mm}$ long, with 12 marginal tentacles and five oral tentacles (Fig. 1d). The two acontioids (terminal region of the second pair of $M$-mesenteries) also appeared, becoming evident in the region near the terminal pore.

The column of the larvae gradually elongated and acquired a tan color. The tentacles also gradually lengthened and became more active, curling and contracting from time to time and in response to external stimuli. After 40-45 days in culture, they reached $1.2 \mathrm{~cm}$ in length, with at least 14 marginal tentacles and 7 labial tentacles (Fig. 1h). Although they still remained in the water column due to the water circulation, the larvae acquired negative buoyancy, tending to stay near the bottom of the culture dish. Just before settling, the larvae had 16 marginal and 9 labial tentacles, and the columns had grown more than 10 times $(1.5 \mathrm{~cm})$ longer than they were at the beginning of the observations. The ciliated epithelium allowed the larvae to move slowly when placed in standing water, but their responses to mechanical stimuli were much faster. Larvae $\mathrm{A}$ and $\mathrm{C}$ developed at almost the same rate. However, Larva B developed more slowly after day 20 (see Table 2).

\section{Settlement}

After 63-119 days in culture, the larvae settled, burrowing into the sand on the bottom of the culture dish, and began to release ptychocysts, producing the first external tube. The small polyps remained in the sediment for 4-7 days before the first exteriorization of the crown of tentacles for feeding. The major modifications observed were a significant lengthening of the column, from $\sim 1.5 \mathrm{~cm}$ before settlement to $4 \mathrm{~cm}$ long after settlement, and the appearance of color bands (brown and milky white) on the tentacles (Fig. 1k, l, Larva A). At this stage, there was a noticeable darkening of the column, which became dark brown in the adult.

\section{Growth and maturation}

After settlement, the polyps started to open their tentacle crowns almost every night when food was offered. Initially the number of tentacles was the same as in the presettlement larvae (16 marginal and 9-10 labial). The polyps were maintained in culture for over 100 days (30-110 days after settlement). Larva A had 28 marginal tentacles and 14 labial ones (Fig. 2, Larva A), and its extended column was $14 \mathrm{~cm}$ long. At this stage, it was possible to observe (by transparency) the presence of early oocytes in the mesenteries. From time to time, the polyp produced a branch of the tube from the aboral end with a new opening (Fig. 3).

\section{Discussion}

\section{Taxonomy}

The validity of planktonic species is an interesting issue in the taxonomy of Ceriantharia. Since the description of the first planktonic species by Sars (1846), a number of different authors followed him, culminating in a long list of "species" and a chaotic pattern. Unfortunately, few authors focused on the consequences of this illogical kind of species descriptions and attempted to correct it. Bourne (1919) discussed the possible relationship of $A$. albida Sars, 1846 with benthic forms in the same area. Picton and Manuel (1985) mentioned “... If Arachnanthus sarsi Carlgren, 1912 were proved to be conspecific with Arachnactis albida Sars, 1846 then the latter, senior name would have priority. The genus Arachnanthus Carlgren, 1912 would become a junior synonym of Arachnactis Sars, 1846 (the type-species being $A$. albida by monotypy) and the valid name of the species would be Arachnactis albida Sars, 1846..." This is an example of how the description of larvae as new species 


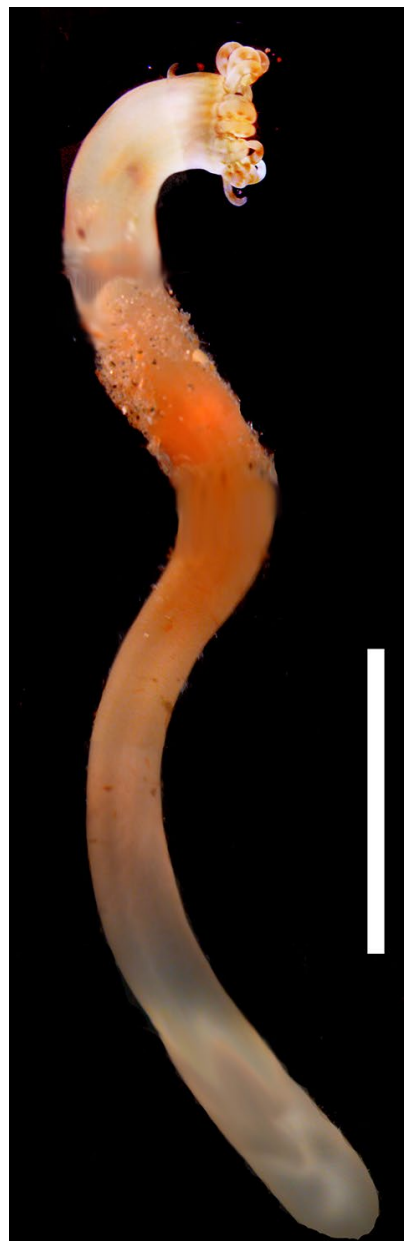

Fig. 2 Adult polyp of Isarachnanthus nocturnus obtained from the developed larva (Larva A). Scale $40 \mathrm{~mm}$

can have serious taxonomic implications, making it difficult to estimate the diversity of the group and requiring great effort to stabilize the nomenclature. Because many investigators have described species based on the planktonic stage alone, 32 genera of Ceriantharia are represented exclusively by planktonic forms, whereas benthic polyps are known for only 8 genera (Molodtsova 2004). Described planktonic species and the kind of studies carried out with each one are listed in Table 3. Almost all the species, pertaining to more than $90 \%$ of the genera, have been described only taxonomically and are otherwise unstudied.

The planktonic morphotype or "planktonic polyp" of Arachnactidae has a superficial resemblance to jellyfish, although its internal anatomy is of a regular young form of Ceriantharia. It is not clear whether this is an evolutionary convergence in body form due to similar selective pressures imposed by the planktonic environment (as is transparency for pelagic animals, e.g., Johnsen 2001), or whether the resemblance is due to a close phylogenetic relationship. The larva of Isarachnanthus resembles the descriptions of a number of planktonic ceriantharians. This is due to the recognition of species and genera based on inconsistent or variable characters (e.g., number and form of tentacles, body size, pigmentation), a practice still in use (e.g., Molodtsova 2003). In fact, a reliable morphological analysis is currently almost impossible because the consistency of the available morphological characters cannot be verified in most cases. Furthermore, in Ceriantharia a number of developmental larval stages of a single benthic form may have been described as different species, because the characters used to delimit the "larval species" change with development (e.g., number and shape of structures).

Our results showed that it is possible to identify larval forms based on different molecular markers (16S, COI, ITS1 and ITS2) and using small amounts of tissue, in this case a piece of tentacle. This approach allows the animals (larvae) to be maintained alive for further developmental observations, without the need to rear them to adults for morphological identification, or to preserve them

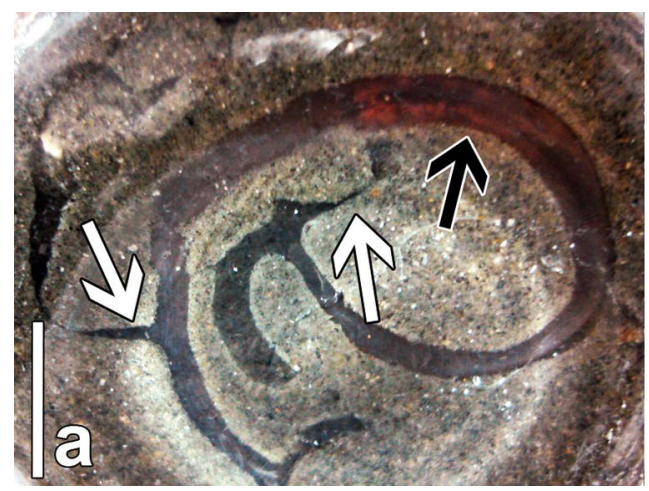

Fig. 3 Horizontal galleries produced by Isarachnanthus nocturnus. a Detail of galleries seen from the underside of the glass container; $\mathbf{b}$ a fragment of galleries taken from the sediment. White arrow bifurca-

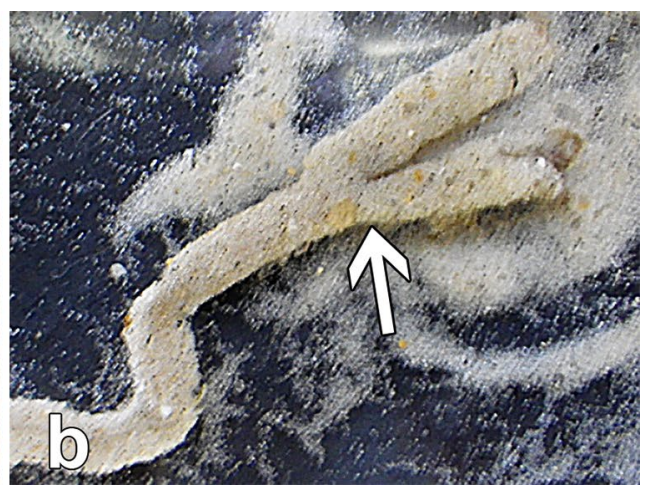

tion of the galleries; black arrow Isarachnanthus polyp seen by transparency within a gallery. Scales $20 \mathrm{~mm}$ 
Table 3 Comparative data for planktonic species and genera of Ceriantharia. For each genus, kind of information available and reference for developmental data are listed

\begin{tabular}{|c|c|c|c|c|}
\hline Family & Genus & $\begin{array}{l}\text { Species with some developmental } \\
\text { information }\end{array}$ & Available information & Developmental references \\
\hline \multicolumn{5}{|c|}{ Arachnactidae } \\
\hline & Anactinia & $\begin{array}{l}\text { A. carlgreni } \\
\text { A. indiana } \\
\text { A. pelagica }\end{array}$ & Development stages described & Nair (1944) \\
\hline & Arachnactis & $\begin{array}{l}\text { A. albida } \\
\text { A. indica } \\
\text { A. sibogae }\end{array}$ & Development stages described & $\begin{array}{l}\text { van Beneden (1898); Carlgren } \\
\text { (1906); McMurrich (1910); } \\
\text { Bourne (1919); Panikkar (1947); } \\
\text { Nair (1944) }\end{array}$ \\
\hline & Bursanthus & & Species descriptions & None \\
\hline & Dactylactis & & Species descriptions & None \\
\hline & Engodactylactis & & Species descriptions & None \\
\hline & Isapiactis & & Species descriptions & None \\
\hline & Isarachnactis & $\begin{array}{l}\text { I. brevis } \\
\text { I. lobiancoi }\end{array}$ & Development stages described & $\begin{array}{l}\text { Carlgren (1924); Calabresi (1928); } \\
\text { Nair (1944) }\end{array}$ \\
\hline & Isovactis & & Species descriptions & None \\
\hline & Nautanthus & & Species descriptions & None \\
\hline & Ovactis & & Species descriptions & None \\
\hline & Paranactinia & & Species descriptions & None \\
\hline & Parovactis & & Species descriptions & None \\
\hline & Sacculactis & & Species descriptions & None \\
\hline \multicolumn{5}{|c|}{ Cerianthidae } \\
\hline & Anthoactis & & Species descriptions & None \\
\hline & Apiactis & A. bengalensis & Development stages described & Panikkar (1936) \\
\hline & Isodactylactis & $\begin{array}{l}\text { I. affinis } \\
\text { I. borealis } \\
\text { I. discors }\end{array}$ & Development stages described & $\begin{array}{l}\text { Carlgren (1924); Calabresi (1927); } \\
\text { Widersten (1998) }\end{array}$ \\
\hline & Paradactylactis & & Species descriptions & None \\
\hline & Peponactis & & Species descriptions & None \\
\hline & Plesiodactylactis & & Species descriptions & None \\
\hline & Solasteractis & & Species descriptions & None \\
\hline & Synarachnactis & S. bournei & Life cycle inferred & Carlgren (1924); Nyholm (1943) \\
\hline & Syndactylactis & & Species descriptions & None \\
\hline & Trichactis & & Species descriptions & None \\
\hline \multicolumn{5}{|c|}{ Botrucnidiferidae } \\
\hline & Angianthula & & Species descriptions & None \\
\hline & Atractanthula & & Species descriptions & None \\
\hline & Botrucnidiata & & Species descriptions & None \\
\hline & Calpanthula & & Species descriptions & None \\
\hline & Cerianthula & C. atlantica & Development stages described & $\begin{array}{l}\text { van Beneden (1924); Carlgren } \\
\text { (1931) }\end{array}$ \\
\hline & Gymnanthula & & Species descriptions & None \\
\hline & Hensenanthula & & Species descriptions & None \\
\hline & Ovanthula & & Species descriptions & None \\
\hline & Sphaeranthula & & Species descriptions & None \\
\hline
\end{tabular}

adequately for additional morphological studies, such as histology, or as voucher specimens. Molodtsova (2004) stated “... due to uniformity in appearance and morphology of benthic Arachnactidae, only the cnidom and the type of planktonic larva can serve as reliable features for taxonomical identification of adult arachnactids." Although in 
Medusozoa the size of the cnidocyst may be useful in species discrimination, in Anthozoa this character is less useful due to the continuous growth of cnidocytes (e.g, Acuña et al. 2011, for sea anemones); this problem may apply particularly to efforts directed at linking larvae to adults of ceriantharians. Furthermore, at least in sea anemones, the complex biometry of the cnidocysts is in part an impediment to their use in taxonomy (Acuña et al. 2011). In the case of Isarachnanthus maderensis and I. nocturnus, Stampar et al. (2012) remarked that "the length of several cnida types of specimens from different areas and different species overlapped and provided weak resolution to distinguish among species."

In many instances, the use of different molecular markers may be a more reliable tool for taxonomic identification than are certain morphological features. This approach has been suggested for other groups and apparently is an efficient method for unambiguously associating the developmental stages of organisms (e.g., Ahrens et al. 2007; Ko et al. 2013). Thus, the development of large molecular databases combined with morphological information is needed. Perhaps only in this way will it be possible to solve a number of taxonomic questions regarding these "larval species" of ceriantharians. The same approach can be applied to any marine taxon for which life cycles are unknown or still not completely known, especially those of species with longlived larval stages and complex life cycles.

Finally, the specimens analyzed in this study and also those treated by Rodriguez et al. (2011) resemble the specimens assigned by van Beneden (1898) to the genus Ovactis. Thus, it will be no surprise if larvae of some other Isarachnanthus species correspond to the genus Ovactis, a question that may be solved in the future with the use of molecular markers as proposed here.

\section{Biology}

The lack of complete information on the life cycle of benthic species of Arachnactidae (Arachnanthus and Isarachnanthus) makes it impossible to compare the larva of I. nocturnus with those of other species of the family. However, for the family Cerianthidae, there is available information about the life cycle of species that have planktonic larvae. Two species, Cerianthus membranaceus and $C$. lloydii, have their life cycle described and are well known (Haime 1854; Nyholm 1943; Riemann-Zürneck 1968), and some features are similar in both groups. The presence of "Nahrungsdotter," a kind of yolk that helps in larvae flotation, metachronous ciliary movement on the tentacles, and "swimming" behavior close to the surface (see further in Riemann-Zürneck 1968) are in accordance with our observations. Furthermore, the descriptions often mention that larvae usually keep the oral region toward the water surface, whereas the larvae of Isarachnanthus almost always position themselves with the mouth toward the bottom. Following settlement, burrowing and metamorphosis, in the first period of benthic life the polyp creeps on the substrate for up to 10 days and then begins to produce the primary tube, as Nyholm (1943) observed for C. lloydii.

In the laboratory, the polyp of I. nocturnus produced a tube system, not a single tube. Hartog (1977), after field observations, reported that the tube of I. nocturnus is not placed in a vertical position, and also supposed that it could in fact be a tube system (although he did not use the term "tube system"). Therefore, based on this evidence, the tube pattern of $I$. nocturnus is quite different from that known for other species of Ceriantharia. The recognized pattern for Ceriantharia is a single tube with only one exit through which the polyp may partly extend (see discussion by Stampar et al. 2015). The tube system with several openings allows the polyp of I. nocturnus to place its feeding tentacles in a favorable position in relation to the water current and may also provide different escape routes from predators.

The São Sebastião Channel contains a relatively large population of I. nocturnus (Stampar et al. 2012). Because the larvae of I. nocturnus were collected at an early stage of development, we presume that they originated in the same or a nearby area in the channel. The long period of planktonic larval life observed in the laboratory indicates that the species may have a high dispersal capacity. Considering the average speed of the Brazil Current $[1.48 \mathrm{~km} / \mathrm{h}$, in conservative estimates (Silveira et al. 2000)] and the life span of the larva in the plankton (63-118 days), the larvae could potentially drift for about $2000-4000 \mathrm{~km}$ along the coast. However, there is no information about the biology and ecology of cerianthid larvae, such as vertical migration, which combined with hydrodynamic conditions could either constrain or foster dispersal. Nevertheless, the species has a wide latitudinal distribution (I. nocturnus, Stampar et al. 2012) that is consistent with a life cycle that includes a larva with high dispersal potential. Stampar et al. (2012) observed a high degree of genetic mixing among populations of the species along the Brazilian coast, which could be explained by dispersal of the long-lived larval stage.

Acknowledgments We are grateful to the Center for Marine Biology of the University of São Paulo (CEBIMar-USP) for providing laboratory and technical support. This study was partly supported by the São Paulo Research Foundation (FAPESP 2010/50174-7 to ACM; FAPESP 2012/01771-8 to SNS; and FAPESP 2012/21583-1 to AEM), and the National Council for Scientific and Technological Development (CNPq 481549/2102-9 to SNS, 301039/2013-5 and 476339/2013-8 to ACM, and 306568/2009-8 to AEM). SNS was supported by CAPES (Coordinating Agency for Advanced Training of Graduate Personnel) through the Postgraduate Program in Zoology, Institute of Biosciences, USP, IBUSP. This is a contribution of the NP-BioMar, USP. 


\section{References}

Acuña FH, Ricci L, Excoffon AC (2011) Statistical relationships of cnidocyst sizes in the sea anemone Oulactis muscosa (Actiniaria: Actiniidae). Belg J Zool 141:32-37

Ahrens D, Monaghan MT, Vogler AP (2007) DNA-based taxonomy for associating adults and larvae in multi-species assemblages of chafers (Coleoptera: Scarabaeidae). Mol Phylogenet Evol 44:436-449

Bernal A, Viñas J, Olivar MP (2014) Genetic support for the morphological identification of larvae of Myctophidae, Gonostomatidae, Sternoptychidae and Phosichthyidae. Sci Mar 78:461-471

Boero F, Bouillon, J, Piraino S (1992) On the origins and evolution of hydromedusan life cycles (Cnidaria, Hydrozoa). In: Dallai R (ed) Sex origin and evolution, selected symposia and monographs U.Z.I., 6, Modena, pp 59-68

Bourne GC (1919) Observations on Arachnactis albida M. Sars. Q J Microsc Sci 64:27-65

Calabresi E (1927) Nuove larve di Ceriantarii. Monit Zool Ital 38:93-110

Calabresi E (1928) Nuove larve di Ceriantarii. Monit Zool Ital 39:1-17

Carlgren O (1906) Die Actinien-Larven. In: Brandt K, Apstein C (eds) Nordisches plankton. Verlag von Lipsius \& Tischer, Kiel and Leipzig, pp 65-89

Carlgren O (1924) Die larven der Ceriantharien, Zoantharien und Actiniarien der deutschen Tiefsee-Expedition mit einen Nachtrag zu den Zoantharien. Wiss Ergebn Dt Tiefsee-Exped 19:339-476

Carlgren O (1931) On some Ceriantharia. Ark Zool 23A:1-10

Cowen RK, Sponaugle S (2009) Larval dispersal and marine population connectivity. Ann Rev Mar Sci 1:443-466

Cunningham CW, Buss LW (1993) Molecular evidence for multiple episodes of paedomorphosis in the family Hydractiniidae. Biochem Syst Ecol 21:57-69

Dawson MN, Jacobs DK (2001) Molecular evidence for cryptic species of Aurelia aurita (Cnidaria, Scyphozoa). Biol Bull 200:92-96

Drummond AJ, Nicholls GK, Rodrigo AG, Solomon W (2002) Estimating mutation parameters, population history and genealogy simultaneously from temporally spaced sequence data. Genetics $161: 1307-1320$

Edgar RC (2004) MUSCLE: multiple sequence alignment with high accuracy and high throughput. Nucleic Acids Res 32:1792-1797

Folmer O, Black M, Hoeh W, Lutz R, Vrijenhoek R (1994) DNA primers for amplification of mitochondrial cytochrome c oxidase subunit I from diverse metazoan invertebrates. Mol Mar Biol Biotechnol 3:294-299

Haime J (1854) Mémoire sur le cérianthe Cerianthus membranaceus. Ann Sci Nat 1:341-389

Hartog JC (1977) Descriptions of two new Ceriantharia from the Caribbean region, Pachycerianthus curacaoensis n. sp. and Arachnanthus nocturnus n. sp., with a discussion of the cnidom and of the classification of the Ceriantharia. Zool Meded $51: 211-248$

Heimeier D, Lavery S, Sewell MA (2010) Using DNA barcoding and phylogenetics to identify Antarctic invertebrate larvae: lessons from a large scale study. Mar Genom 3:165-177

Jarms G (1990) Neubeschreibung dreier Arten der Gattung Nausithoe (Coronata, Scyphozoa) sowie Wiederbeschreibung der Art Nausithoe marginata Kölliker, 1853. Mitt Hambg Zool Mus Inst 87:7-39

Jarms G, Morandini AC, Silveira FL (2002) Cultivation of polyps and medusae of Coronatae (Cnidaria, Scyphozoa) with a brief review of important characters. Helgol Mar Res 56:203-210
Ji Y-J, Zhang D-X, He L-J (2003) Evolutionary conservation and versatility of a new set of primers for amplifying the ribosomal internal transcribed spacer regions in insects and other invertebrates. Mol Ecol Notes 3:581-585

Johnsen S (2001) Hidden in plain sight: the ecology and physiology of organismal transparency. Biol Bull 201:301-318

Ko H-L, Wang Y-T, Chiu T-S, Lee M-A, Leu M-Y, Chang K-Z et al (2013) Evaluating the accuracy of morphological identification of larval fishes by applying DNA barcoding. PLoS One 8:e53451. doi:10.1371/journal.pone.0053451

Leloup E (1964) Larves de Cerianthaires. Discov Rep 33:251-307

McMurrich JP (1910) The genus Arachnactis. J Exp Zool 9:159-168

Minelli A, Fusco G (2010) Developmental plasticity and the evolution of animal complex life cycles. Philos Trans R Soc B 365:631-640

Molodtsova TN (2003) On Isarachnanthus from Central Atlantic and Caribbean region with notes on Isarachnactis lobiancoi (Carlgren, 1912). Zool Verh 345:249-255

Molodtsova TN (2004) On the taxonomy and presumable evolutionary pathways of planktonic larvae of Ceriantharia (Anthozoa, Cnidaria). Hydrobiologia 530(531):261-266

Nair RV (1944) On the larval Ceriantharia from the Madras plankton. Curr Sci 13:132-133

Naumov DV (1969) Hydroids and hydromedusae of the USSR. Fauna U.S.S.R. 70:1-660. Israel Program for Scientific Translations, cat. no. 5108

Nyholm KG (1943) Zur Entwicklung und Entwicklungsbiologie der Ceriantharien und Aktinien. Zool Bidr Upps 22:87-248

Panikkar NK (1936) On Apiactis bengalensis, species nova, a new pelagic larval ceriantharian from the Madras plankton. Zool Anz 140:250-260

Panikkar NK (1947) Observations on the structure and developmental stages of a new species of Arachnactis from the Madras plankton. Ann Sci Nat 9:227-250

Picton BE, Manuel RL (1985) Arachnanthus sarsi Carlgren, 1912-a redescription of a cerianthid anemone new to the British-Isles. Zool J Linn Soc 83:343-349

Riemann-Zürneck K (1968) Cerianthus-Larven aus dem Weserästuar. Veröff Inst Meeresforsch 11:37-45

Rodriguez CS, Marques AC, Stampar SN, Morandini AC, Christiansen E, Genzano G, Mianzan H (2011) The taxonomic position of the pelagic staurozoan Tessera gemmaria as a ceriantharian larva. Zootaxa 2971:49-58

Sars M (1846) Ueber Arachnactis albida, einen schwimmenden Polypen. In: Sars M (ed) Fauna littoralis Norvegiae oder Beschreibung und Abbildungen neuer oder wenig bekannten Seethiere, nebst Beobachtungen über die Organisation, Lebensweise und Entwickelung derselben. Druck und Veblag von Johann Dahl, Christiana, pp 28-30

Silveira ICA, Schmidt ACK, Campos EJD, Godoi SS, Ikeda Y (2000) A Corrente do Brasil ao largo da Costa Leste Brasileira. Rev Bras Oceanogr 48:171-183

Stampar SN, Morandini AC (2014) Occurrence of Isarachnanthus (Cnidaria: Anthozoa: Ceriantharia) at Ascension Island: a test of hypothesis. J Mar Biol Assoc UK. doi:10.1017/ S0025315414000423

Stampar SN, Maronna MM, Vermeij MJA, Silveira FLd, Morandini AC (2012) Evolutionary diversification of banded tubedwelling anemones (Cnidaria; Ceriantharia; Isarachnanthus) in the Atlantic Ocean. PLoS One 7:e41091. doi:10.1371/journal. pone.0041091

Stampar SN, Maronna MM, Kitahara MV, Reimer JD, Morandini AC (2014a) Fast-evolving mitochondrial DNA in Ceriantharia: a reflection of Hexacorallia paraphyly? PLoS One 9:e86612. doi:10.1371/journal.pone. 0086612 
Stampar SN, Morandini AC, Silveira FL (2014b) A new species of Pachycerianthus (Cnidaria, Anthozoa, Ceriantharia) from Tropical Southwestern Atlantic. Zootaxa 3827:343-354. doi:10.11646/zootaxa.3827.3.4

Stampar SN, Beneti JS, Acuña FH, Morandini AC (2015) Ultrastructure and tube formation in Ceriantharia (Cnidaria, Anthozoa). Zool Anz 254:67-71. doi:10.1016/j.jcz.2014.11.004

Tamura K, Peterson D, Peterson N, Stecher G, Nei M, Kumar S (2011) MEGA5: molecular Evolutionary Genetics Analysis using maximum likelihood, evolutionary distance, and maximum parsimony methods. Mol Biol Evol 28:2731-2739

Tiffon Y (1987) Ordre des Cérianthaires. In: Grassé P (ed) Traité de Zoologie: Anatomie, Systématique, Biologie - Cnidaires/Anthozoaires - Tome III. Masson, Paris, pp 210-256
Uchida H (1979) Cerianthids (Anthozoa, Coelenterata) from Kii Region, Middle Japan. Mem Natl Sci Mus Tokyo 12:185-199

van Beneden E (1898) Les Anthozoaires de la "Plankton-Expedition". Erg Plank-Exp Humbolt-Stiftung 2:1-222

van Beneden E (1924) Travaux posthumes d'Edouard van Beneden sur les cérianthaires collationnés par Paul Cerfontaine. Arch Biol (hors serie):1-242

Weeb KE, Barnes DKA, Clark MS, Bowden DA (2006) DNA barcoding: a molecular tool to identify Antarctic marine larvae. Deep Sea Res Part II 53:1053-1060

Widersten B (1998) On Isodactylactis borealis, a new species of cerianthid larvae. Helgol Meeresunters 52:111-114 